\title{
ALIRAN ANTROPOLGI HUKUM
}

Nama : Dwi Mega Putri

Email : banpur65@gmail.com

No Bp : 2010003600293

Kelas : 1 H8

Prodi : Ilmu Hukum

\section{Perguruan Tinggi : UNIVERSITAS EKASAKTI}

\section{A. PENDAHULUAN}

Antropologi secara etimologis berasal dari bahasa Yunani. Kata Anthropos berarti mansia dan logos berarti ilmu pengetahuan. Jadi, antropologi adalah ilmu yang mempelajari manusia. Oleh karena itu antropologi didasarkan pada kemajuan yang telah dicapai ilmu pengetahuna sebelumnya.

Pitirim Sorokim mengatakan bahwa Sosiologi adalah suatu ilmu yang mempelajari hubungan dan pengaruh timbal balik antara aneka macam gejala - gejala sosial (gejala ekonomi dengan agama, keluarga dengan moral, hukum dengan ekonomi) dengan gejala lainnya (nonsosial).

Berbeda dengan pendapat Rouceke dan Warren yang mengatakan bahwa Sosiologi adalah ilmu yang mempelajari hubungan manusia dengan kelompok-kelompok. Nah berasarkan uraian di atas, maka Sosiologi adalah jelas merupakan ilmu sosial yang objeknya adalah masyarakat sebagai ilmu. Ia berdiri sendiri karena telah memiliki unsur ilmu pengetahuan.

Dalam ilmu antropologi hukum dipelajari juga mengenai Peran, Status atau kedudukan, Nilai, Norma dan juga Budaya atau kebudayaan. Kesemuanya ini merupakan hal-hal yang sangat erat kaitannya dengan ilmu antropologi hukum. Memberikan gambaran teori mengenai Peran, Status, Nilai, Norma, dan juga 
Budaya/kebudayaan dalam kaitannya dengan masyarakat sebagai sasaran ilmu Sosiologi. Sebagai arahan agar saya sebagai mahasiswa dapat mengkorelasikan hubungan antara teori Peran, Status, Nilai, Norma dan Budaya/kebudayaan dengan kehidupan masyarakat di kehidupan yang nyata.

Antropologi melihat hukum hanya sebagai aspek dari kebudayaan, yaitu suatu aspek yang digunakan oleh kekuasaan masyarakat yang teratur dalam mengatur perilaku dan masyarakat, agar tidak terjadi penyimpangan dan penyimpangan yang terjadi dari norma-norma sosial yang ditentukan dapat diperbaiki.

Antropologi hukum merupakan cabang ilmu pengetahua hukum yang mempelajari pola-pola sengketa dan penyelesaiannya, baik pada masyarakat yang sederhana maupun pada masyarakat yang mengalami modernisasi. Batasan ini dikemukakan oleh Paul Bohanan.

Menurut J.B. Daliyo dkk, antropologi hukum adalah antropologi yang mempelajari hukum sebagai salah satu aspek kebudayaan. Kemudian Hilman Hadikusuma memberikan pendapat mengenai antropologi hukum sebagai ilmu pengetahuan yang mempelajari manusia dengan kebudayaan yang khusus di bidang hukum. 


\section{B. PEMBAHASAN}

\section{A. Pengertian Antropologi}

Antropologi berasal dari kata Yunani óv $\theta \rho \omega \pi$ (baca: anthropos) yang berarti "manusia" atau "orang", dan logos yang berarti ilmu. Antropologi mempelajari manusia sebagai makhluk biologis sekaligus makhluk sosial. Antropologi memiliki dua sisi holistik dimana meneliti manusia pada tiap waktu dan tiap dimensi kemanusiannya. Arus utama inilah yang secara tradisional memisahkan antropologi dari disiplin ilmu kemanusiaan lainnya yang menekankan pada perbandingan/ perbedaan budaya antar manusia. Walaupun begitu sisi ini banyak diperdebatkan dan menjadi kontroversi sehingga metode antropologi sekarang seringkali dilakukan pada pemusatan penelitan pada pendudukyang merupakan masyarakat tunggal.

a. Definisi Antropologi menurut para ahli

David Hunter: Antropologi adalah ilmu yang lahir dari keingintahuan yang tidak terbatas tentang umat manusia.

Koentjaraningrat: Antropologi adalah ilmu yang mempelajari umat manusia pada umumnya dengan mempelajari aneka warna, bentuk fisik masyarakat serta kebudayaan yang dihasilkan. William A. Havilan: Antropologi adalah studi tentang umat manusia, berusaha menyusun generalisasi yang bermanfaat tentang manusia dan perilakunya serta untuk memperoleh pengertian yang lengkap tentang keanekaragaman manusia.

Dari definisi tersebut, dapat disusun pengertian sederhana antropologi, yaitu sebuah ilmu yang mempelajari manusia dari segi keanekaragaman fisik serta kebudayaan (cara-cara berprilaku, tradisi-tradisi, nilai-nilai) yang dihasilkan sehingga setiap manusia yang satu dengan yang lainnya berbeda-beda. 


\section{b. Sejarah}

Seperti halnya sosiologi, antropologi sebagai sebuah ilmu juga mengalami tahapan-tahapan dalam perkembangannya. Koentjaraninggrat menyusun perkembangan ilmu Antropologi menjadi empat fase sebagai berikut:

- Fase Pertama (Sebelum tahun 1800-an)

Manusia dan kebudayaannya, sebagai bahan kajian Antropologi. Sekitar abad ke-15-16, bangsa-bangsa di Eropa mulai berlomba-lomba untuk menjelajahi dunia. Mulai dari Afrika, Amerika, Asia, hingga ke Australia. Dalam penjelajahannya mereka banyak menemukan hal-hal baru. Mereka juga banyak menjumpai suku-suku yang asing bagi mereka. Kisah-kisah petualangan dan penemuan mereka kemudian mereka catat di buku harian ataupun jurnal perjalanan. Mereka mencatat segala sesuatu yang berhubungan dengan suku-suku asing tersebut. Mulai dari ciri-ciri fisik, kebudayaan, susunan masyarakat, atau bahasa dari suku tersebut. Bahan-bahan yang berisi tentang deskripsi suku asing tersebut kemudian dikenal dengan bahan etnografi atau deskripsi tentang bangsa-bangsa.

Bahan etnografi itu menarik perhatian pelajar-pelajar di Eropa. Kemudian, pada permulaan abad ke-19 perhatian bangsa Eropa terhadap bahan-bahan etnografi suku luar Eropa dari sudut pandang ilmiah, menjadi sangat besar. Karena itu, timbul usaha-usaha untuk mengintegrasikan seluruh himpunan bahan etnografi.

- Fase Kedua (tahun 1800-an)

Pada fase ini, bahan-bahan etnografi tersebut telah disusun menjadi karangan-karangan berdasarkan cara berpikir evolusi masyarakat pada saat itu. masyarakat dan kebudayaan berevolusi secara perlahan-lahan dan dalam jangka waktu yang lama. Mereka menganggap 
bangsa-bangsa selain Eropa sebagai bangsa-bangsa primitif yang tertinggal, dan menganggap Eropa sebagai bangsa yang tinggi kebudayaannya

Pada fase ini, Antopologi bertujuan akademis, mereka mempelajari masyarakat dan kebudayaan primitif dengan maksud untuk memperoleh pemahaman tentang tingkat-tingkat sejarah penyebaran kebudayaan manusia.

- Fase Ketiga (awal abad ke-20)

Pada fase ini, negara-negara di Eropa berlomba-lomba membangun koloni di benua lain seperti Asia, Amerika, Australia dan Afrika. Dalam rangka membangun koloni-koloni tersebut, muncul berbagai kendala seperti serangan dari bangsa asli, pemberontakanpemberontakan, cuaca yang kurang cocok bagi bangsa Eropa serta hambatan-hambatan lain. Dalam menghadapinya, pemerintahan kolonial negara Eropa berusaha mencari-cari kelemahan suku asli untuk kemudian menaklukannya.

Untuk itulah mereka mulai mempelajari bahan-bahan etnografi tentang suku-suku bangsa di luar Eropa, mempelajari kebudayaan dan kebiasaannya, untuk kepentingan pemerintah kolonial.

- Fase Keempat (setelah tahun 1930-an)

Pada fase ini, Antropologi berkembang secara pesat. Kebudayaan-kebudayaan suku bangsa asli yang di jajah bangsa Eropa, mulai hilang akibat terpengaruh kebudayaan bangsa Eropa. Pada masa ini pula terjadi sebuah perang besar di Eropa, Perang Dunia II. Perang ini membawa banyak perubahan dalam kehidupan manusia dan membawa sebagian besar negara-negara di dunia kepada kehancuran total. Kehancuran itu menghasilkan kemiskinan, kesenjangan sosial, dan kesengsaraan yang tak berujung. 
Namun pada saat itu juga, muncul semangat nasionalisme bangsa-bangsa yang dijajah Eropa untuk keluar dari belenggu penjajahan. Sebagian dari bangsa-bangsa tersebut berhasil mereka. Namun banyak masyarakatnya yang masih memendam dendam terhadap bangsa Eropa yang telah menjajah mereka selama bertahun-tahun.

Proses-proses perubahan tersebut menyebabkan perhatian ilmu antropologi tidak lagi ditujukan kepada penduduk pedesaan di luar Eropa, tetapi juga kepada suku bangsa di daerah pedalaman Eropa seperti suku bangsa Soami, Flam dan Lapp.

\section{B. Antropologi Dalam Konteks Pengetahuan Di Indonesia}

Secara umum masyarakat Indonesia akan mengenal Pak Koen (Koentjaraningrat-red) sebagai Bapak Antropologi Indonesia mengingat peran dan jasanya dalam mengembangkan ilmu antropologi di Indonesia, hanya saja peran dan jasanya tersebut akan kita pertanyakan kembali pada saat sekarang ini, relevankah pada saat sekarang ini ?.

Sejarah perkembangan ilmu antropologi di Indonesia tidak lepas dari peran para sarjana Indonesia yang mengecap pendidikan ilmu antropologi di daerah perkembangannya (Amerika Serikat, Eropa, dan negara lainnya di luar Asia). Pengetahuan yang mereka gali tentang antropologi pada masa awal perkembangannya menjadikan diri mereka "the one and only" di negara Indonesia ini. Tulisan ini tidaklah untuk menyudutkan mereka-mereka yang telah bersusah payah mengembangkan ilmu antropologi di Indonesia namun untuk menyadarkan bahwa ilmu bukanlah milik perorangan namun ilmu dilihat sebagai suatu kebebasan dalam berekspresi menurut kaidah ilmu itu sendiri sehingga hal ini memungkinkan untuk menjadikan seseorang memiliki pendapat sendiri terhadap suatu masalah dan tidak menjadikan pendapat seorang menjadi rujukan akhir. 
Dalam proses perkembangannya ilmu antropologi di Indonesia secara umum mengerucut menjadi ilmu yang menjadi penopang proses "pembangunan", hal ini menjadi rancu ketika para mahasiswa diajarkan untuk berusaha berfikir bukan diajarkan untuk bersandar pada pendapat yang telah ada tanpa adanya proses metodologis terlebih dahulu. Perkembangan tersebut menjadi terhenti ketika para antropolog berlomba-lomba untuk menjadi "agen pembangunan" dalam artian sebagai makelar proyek pembangunan yang secara eksplisit merupakan penistaan terhadap ilmu yang diperolehnya melalui serangkaian proses pendidikan, hal ini dapat dilihat secara kasat mata dengan hilangnya mata pelajaran antropologi dalam kurikulum sekolah menengah atas, apakah ini merupakan tindakan yang tidak disengaja ataukah usaha untuk mengkerdilkan peran antropolog atau juga suatu usaha untuk menjadikan ilmu antropologi sebagai suatu ilmu yang tidak tepat guna?.

Pada bagian ini akan ditutup dengan pernyataan bahwa sebagai cabang ilmu pengetahuan, antropologi memiliki kebebasan bagi para penganutnya untuk menjadikan ilmu antropologi sebagai pengetahuan untuk berfikir dan bertindak.

C. Pentas Antropologi di Indonesia

Di Indonesia ilmu modern sangat terkait dengan "nilai guna". Di bawah rezim pembangunan, ruang untuk berfilsafat sangat sempit. Kalau pengetahuan tidak punya aplikasi langsung, dianggap tidak penting, malahan membingungkan atau membahayakan masyarakat yang seharusnya "berpembangunan-ria" Kewarganegaraan seseorang didefinisikan dengan penilaian sejauh mana intelektualitas, maupun subyektivitas, bisa ditujukan pada pengabdian negara dan modal. Demikian pula status antropologi yang berfungsi sebagai abdi-dalem pemerintah dan jarang memberi kesempatan kepada pemikir tandingan.

Namun, kecenderungan antropologi di Indonesia mendukungi status quo tidak bisa dibebankan hanya pada dosa Orde Baru. Asal-usul antropologi, di Barat maupun di 
Indonesia, terkait intim dengan sejarah kolonialisme. Para pejabat kompeni pada zaman dulu wajib menulis laporan bukan hanya tentang daerah yang akan diambil atau sumber daya alam yang akan dieksploitasi, tetapi tentang karakter masyarakat yang sedang dijajah.

Catatan semacam ini diberi nama etnologi, menawarkan penggambaran watak khas suatu masyarakat. Informasi ini digunakan untuk mempermudah penguasaan kaum pribumi. Antropologi menjadi sebuah teknologi utama guna menjalankan kontrol sosial serta memungkinkan pola penjajahan dengan sistem indirect rule: penundukan dilaksanakan melalui institusi lokal dan pemimpin setempat dengan kodifikasi hegemoni lokal atas nama adat.

Penekanan pada katalog perbedaan budaya memunculkan apa yang pernah diidentifikasikan oleh kritikus sastra, Homi Bhabha, sebagai paradoks kolonialisme: yang dijajah disuruh menjadi white but not quite, atau diajak berpartisipasi dalam struktur penjajahan lewat perbedaan mereka. Dari satu sisi, keaslian masyarakat dianggap, menurut "kebijakan etis" Belanda, sebagai sesuatu yang harus dijaga untuk mencegah yang lemah dari pencemaran gelombang "baratisasi". Tetapi, dari sisi lain, sistem ketidakadilan sosial diperkuat dengan melestarikan kelemahan tersebut.

D. Peranan Ahli Antropologi Kesehatan terhadap Penanganan Masalah Kesehatan Masyarakat

Peranan antropologi dalam menangani masalah kesehatan. Fokus program-program tersebut pada penanganan kebiasaan buruk yang menyebabkan sakit, penanganan partisipasi masyarakat memanfaatkan pelayanan kesehatan yang disediakan pemerintah, meningkatkan mutu pelayanan kesehatan dengan memperhatikan kualitas manusia tenaga kesehatan dan penanganan dampak ekologi terhadap kesehatan manusia. Seperti sudah diuraikan di atas bahwa antropologi kesehatan mengkaji biokultural kesehatan manusia dan ini berarti 
penggunaan tenaga antropologi sangat dibutuhkan dalam penanganan program-program kesehatan tersebut. Atau tenaga kesehatan yang bekerja di Dinas Kesehatan Provinsi Papua yang tersebar diberbagai kabupaten kota di Papua perlu memiliki pengetahuan antropologi kesehatan dalam mengatasi masalah-masalah praktis yang mereka hadapi di lapangan. Penggunaan tenaga antropologi kesehatan dalam program-program pembangunan kesehatan,. keterlibatan tenaga antropologi kesehatan dipakai untuk riset-riset tertentu saja, tetapi belum pernah digunakan dalam perencanaan pembangunan kesehatan, keterlibatan sebagai konsultan dalam penanganan kegiatan program kesehatan di Dinas Kesehatan.

E. Peranan Antropologi Dan Partisipasi Masyarakat Dalam Memamfaatkan Pelayanan Kesehatan Yang Disediakan Pemerintah

Antropologi mempunyai metode yang khas dan tidak dimiliki oleh ilmu-ilmu lain, yaitu Observasi partisipasi. Metode ini yang sering menghebohkan dunia ilmu pengetahuan dengan penemuan-penemuan baru yang sangat berguna dalam membangun suatu masyarakat. Kadang-kadang di lingkungan dunia "praktis", cara masuk untuk menumbuhkan partisipasi masyarakat sangat lambat dan bahkan tidak berhasil karena pendekatan yang digunakan keliru. Ilmu Antropologi memahami kebudyaan manusia dan mengerti orientasi nilai dalam suatu masyarakat yang menjadi acuan dalam hidupnya untuk melakukan sesuatu (partisipasi dalam bahasa dunia “praktis").

F. Peranan Antropologi Kesehatan Dalam Pembangunan Masyarakat

Dalam bagian ini saya akan menguraikan peranan Antropologi Kesehatan dalam menjalankan program-program pembangunan yang direncanakan untuk memberikan perawatan kesehatan yang lebih baik pada masyarakat. Ini berarti merupakan penerapan masalah pengetahuan Antropologi Kesehatan dan konsekuensinya. 


\section{PENUTUP}

Antropologi adalah ilmu yang mempelajari manusia. Oleh karena itu antropologi didasarkan pada kemajuan yang telah dicapai ilmu pengetahuan sebelumnya. Pengertian Antropologi dapat dilihat dari 2 sisi yaitu Antropologi sebagai ilmu pengetahuan artinya bahwa Antropologi merupakan kumpulan pengetahuan-pengetahuan tentang kajian masyarakat dan kebudayaan yang disusun secara sistematis atas dasar pemikiran yang logis. Dan pengertian Antropologi yang kedua adalah cara-cara berpikir untuk mengungkapkan realitassosial dan budaya yang ada dalam masyarakat dengan prosedur dan teori yang dapat dipertanggungjawabkan kebenarannya secara ilmiah.

Setelah di kaji kita dapat mengemukakan hasilnya bahwa manfaat di dalam antropologi hukum sangat luas.Antropologi hukum telah memberikan kontribusi yang sangat besar bangi perkembangan ilmu hukum.Dan kesimpulan yang dapat diambil adalah dimana pun kita ,kita tidak akan pernah jauh dari hukum selama kita berada di Negara hukum.

Peranan adalah aspek dinamis dari kedudukan, yaitu seorang yang melaksanakan hak-hak dan kewajibannya.Status adalah tempat atau posisi seseorang dalam suatu kelompok sosial. Sedangkan kedudukan sosial (social status) artinya tempat seseorang secara umum dalam masyarakatnya sehubungan dengan orang lain, dalam arti lingkungan pergaulannya, prestisenya, dan hak-hak serta kewajiban-kewajibannya.

Namun untuk mempermudah dalam pengertiannya maka dalam kedua istilah di atas akan dipergunakan dalam arti yang sama dan digambarkan dengan istilah "kedudukan" (status) saja. Nilai (Nilai Sosial) adalah nilai yang dianut oleh suatu masyarakat, mengenai apa yang dianggap baik dan apa yang dianggap buruk oleh masyarakat. Norma adalah seluruh kaidah dan peraturan yang diterapkan melalui lingkungan sosialnya. Budaya adalah hal-hal yang berkaitan dengan budi dan akal manusia. Kebudayaan merupakan keseluruhan pengertian, nilai, norma, ilmu pengetahuan serta keseluruhan struktur-struktur sosial, religius, dan lain- 
lain, tambahan lagi segala pernyataan intelektual dan artistik yang menjadi ciri khas suatu masyarakat. 


\section{DAFTAR PUSTAKA}

Soekanto, Soerjono. Prof. Dr. 1984. Antropologi Hukum. Jakarta: CV. Rajawali

Wignjodipuro, Surojo. S.H. 1968. Pengantar Dan Asas-Asas Hukum Adat. Jakarta: Gunung Agung.

Huky, Wila. Drs. D. A. 1986. Antropologi. Surabaya: Usaha Nasional

Koentjaraningrat. Prof. Dr. 2009. Pengantar Ilmu Antropologi. Jakarta: Rineka Cipta.

M. J. Herskovits.2006. Antropologi Suatu Pengantar. Jakarta : PT Raja Grafindo Persada Ensiklopedi Indonesia, 16.45, 18 Februari 2009 http://www.id.wikipedia.org 